\title{
An Analysis of Convergence Core Competency Affecting Team Creativity of Industrial Workers
}

\author{
EunJoo Kim \\ Eulji University, Geonggido, South Korea \\ kej70@eulji.ac.kr
}

\begin{abstract}
Future societies emphasize that an important factor of team creativity is the collaboration between people with creative talent and people with expertise in various fields. Therefore, this study aimed to analyze the effect of the convergence core competency of industrial workers on team creativity. For this purpose, 104 industrial workers were studied to investigate the impact of convergence core competency on team creativity. The effect of convergence core competency of industrial workers on team creativity was analyzed. The analysis results show that creative thinking and consideration affect team creativity as well as industrial workers' convergence core competency. Thus, in the future, educational content centered on convergence core competency should be developed in the university education field to enhance the sustainable growth of team creativity that. In particular, research on educational methodologies that can enhance creative thinking and consideration should be actively conducted.
\end{abstract}

Keywords: Convergence core competency, Team creativity, Industrial workers

\section{Introduction}

The recognition that it is important to cultivate creative talents in terms of industry competitiveness has already started in the United States, while Korea also attempted to systematically develop a convergent talent education research program in 2011 [1]. In order to adapt to new technological change in the country, a priority is to cultivate talented people who have core competencies in convergence [2]. In particular, as a part of innovation in industry, abandoning the seniority-based personnel system and applying the concept of competency to new personnel management is key [3]. In addition, interview questions based on the competency models of companies such as Apple and Google are increasingly being used to test creativity. According to surveys of domestic companies, $82 \%$ of the top 100 companies were building competency models by the year 2005, and $77 \%$ of them conduct competency evaluations [4].

Core competencies can better predict job performance than intelligence [5]. These variables should be measured rather than intelligence because they are not affected by socioeconomic factors such as race, sex, and economic power. However, a point of caution here is that creativity among different competencies varies according to gender, according to in a study by Kay and Koval [6], who reported that men are more creative than women. These results are intended only for Americans and may be based on certain cultural interpretations.

Article history:

Received (April 21, 2020), Review Result (May 27, 2020), Accepted (July 3, 2020) 
As such, competency represents a variety of research results, depending on social and cultural aspects [7]. Competency is used as a criterion for companies to place employees in the right positions and to evaluate performance [8]. In other words, convergence core competency represents an important independent variable used to derive high organizational performance. In addition, the emergence of the terms participation, sharing, and collaboration within an organization shows that importance is placed on the performance of the individual as well as the performance of the team.

One of the major changes in the organization of modern society is the expansion of team work [9]. Modern organizations have reorganized existing departments to perform tasks efficiently and increase synergy among members. For example, more than $80 \%$ of Korean companies have already reported the adoption of team-based organization [10]. In the context of teamwork, team adaptations through the interaction with team members includes concepts that are different from individual adaptations. In other words, at the team level, communication between the members is conducted through the network and tasks also change interdependently. Therefore, new changes such as employing a team structure as well as ability and goal-oriented behavior and cognition can be explained by creative innovation in team adaptation [11].

While the focus was on creative talent, or creative members, as a key element for companies to survive in the global competition structure, gradually, the activities of team units have increased, and various ways to bring each individual member to the team and organizational level in a large context rather than the creativity level of the individual members. Accordingly, in this study, we would like to analyze the impact of convergence core competency on team creativity, focusing on industry workers. The hypotheses of the studies established to achieve these research objectives are as follows:

Hypothesis 1 . The convergence core competency and team creativity of industry workers will be significant.

Hypothesis 2. The convergence core competency of industry workers will affect team creativity.

\section{Research methodology}

\subsection{Subject}

This study examines the effect of the convergence core competency of industry workers on team creativity. The research was conducted from September 4th to 28th, 2018 by random sampling method for workers in industries in their 20 s and older who worked in the Seoul metropolitan area for two weeks. The data collection method was conducted through an online survey. A total of 104 respondents were analyzed, except for those with high double missing points. The general characteristics of the study subjects used in the analysis are shown in [Table 1].

Table 1. General characteristics (N=104)

\begin{tabular}{|c|c|c|c|}
\hline \multicolumn{2}{|c|}{ Observation variable } & Frequency (persons) & Percent (\%) \\
\hline \multirow{2}{*}{ Gender } & Male & 57 & 54.8 \\
\cline { 2 - 4 } & Female & 47 & 45.2 \\
\hline \multirow{2}{*}{ Age } & $20 \sim 30$ & 20 & 19.2 \\
\cline { 2 - 4 } & $31 \sim 40$ & 26 & 25.0 \\
\hline
\end{tabular}




\begin{tabular}{|c|c|c|c|}
\hline & $41 \sim 50$ & 30 & 28.8 \\
\hline & $51 \sim 60$ & 22 & 21.2 \\
\hline & More than 60 years & 6 & 5.8 \\
\hline \multirow{5}{*}{ Career } & Less than 5 years & 29 & 27.9 \\
\hline & $5 \sim 10$ years & 23 & 22.1 \\
\hline & $11 \sim 20$ years & 27 & 26.0 \\
\hline & $21 \sim 30$ years & 19 & 18.3 \\
\hline & More than 31 years & 6 & 5.8 \\
\hline \multirow{5}{*}{ Education } & High school graduation & 1 & 1.0 \\
\hline & College graduation & 10 & 9.6 \\
\hline & University graduation & 49 & 47.1 \\
\hline & Master & 24 & 23.1 \\
\hline & Doctor & 20 & 19.2 \\
\hline \multirow{5}{*}{ Work scale } & Less than 10 & 40 & 38.5 \\
\hline & $10 \sim 100$ & 38 & 36.5 \\
\hline & $100 \sim 300$ & 8 & 7.7 \\
\hline & $300 \sim 500$ & 6 & 5.8 \\
\hline & More than 500 & 12 & 11.5 \\
\hline \multirow{5}{*}{ Job field } & Service position & 17 & 16.3 \\
\hline & Management, office workers & 41 & 39.4 \\
\hline & A business position & 14 & 13.5 \\
\hline & A professional job & 27 & 26.0 \\
\hline & Other & 5 & 4.8 \\
\hline
\end{tabular}

Among the general characteristics of the subjects, In the case of sex, 57(54.8\%) were male and $47(45.2 \%)$ were female. The age distribution was the largest among those aged 41 to 50, with $30(28.8 \%)$. Career was less than 5 years, and education was the highest University graduation with 49(47.1\%). The work scale was the largest with 40(38.5\%), and job field distribution had the highest management, office workers with 41(39.4\%).

\subsection{Measuring instrument}

This study is to identify the convergence core competency that affect team creativity of industrial workers. The composition of the questionnaire consists of six questions asking demographic characteristics, nine questions asking the current level of the convergence core competency, 24 questions asking the level of team creativity, and a total of 39 questions.

Table 2. Question composition

\begin{tabular}{|l|c|c|c|}
\hline \multicolumn{2}{|c|}{ division } & $\begin{array}{c}\text { Number of } \\
\text { questions }\end{array}$ & Cronbach' $\alpha$ \\
\hline Demographic information & $\begin{array}{c}\text { Gender, age, career, educational, } \\
\text { work scale, job field }\end{array}$ & 6 & - \\
\hline
\end{tabular}




\begin{tabular}{|c|c|c|c|}
\hline convergence core capacity & $\begin{array}{c}\text { Creative thinking, critical thinking, converged } \\
\text { knowledge, problem solving, communication, } \\
\text { cooperation, use of convergence tools, } \\
\text { consideration, responsibility }\end{array}$ & 9 & .903 \\
\hline team creativity & $\begin{array}{c}\text { Diversity (4), Leadership (8), Derivation of Idea } \\
\text { (7), Autonomy (5) }\end{array}$ & 24 & .911 \\
\hline
\end{tabular}

The convergence core competency framework developed by Park Ki-moon (2014) was used for the analysis [12]. The convergence core competency are divided into converged cognitive capabilities (creative thinking, critical thinking, and converged knowledge), converged performance capabilities (using problem-solving, communication, cooperation, and convergence tooling), and converged attitude capabilities (attention, responsibility). The Cronbach' alpha value was calculated to ensure the reliability of the measuring tool. The reliability Cronbach' $\alpha$ value of the question asking the current level of convergence core capacity was .903 . For each sub clause, the Likert 5-point scale was used with 1 point 'very low', 2 point 'low', 3 point 'ordinary', 4 point 'high' and 5 point 'very high'. Team creativity was used to correct and supplement the questions used in the study by Choi Jong-in and Kim Hak-soo for the purpose of this study [13]. Team creativity was divided into four subdimensiones: idea elicitation, diversity, leadership and autonomy, and consisted of seven, four, eight, and five questions, respectively, measured on a five-point scale of the recertion. The reliability of the item asking team creativity was 0.911. The variables of each sub content were used as Likert 5 point scale with 1 point of 'very low', 2 points of 'low', 3 points of 'normal', 4 points of 'high' and 5 points of 'very high'.

\subsection{Data analysis}

To analyze the problems of this study, the collected data were analyzed using the PASW Statistics 18.0 program. Cronbach's alpha coefficients were calculated to determine the internal consistency of the survey instruments. The minimum value, maximum value, average, and standard deviation were calculated to analyze the convergence core competency and team creativity level of industrial workers. Pearson correlation analysis was conducted to explore the relationship between convergence core competency and team creativity. Finally, a simple regression analysis was conducted to analyze the effects of the convergence core competency of industrial workers on team creativity.

\section{Result}

\subsection{Hypothesis 1 - The convergence core competency and team creativity of industry workers will be significant}

Before validating the hypothesis of this study, technical statistics were calculated to identify the convergence core competency and level of team creativity of industry workers. The results are shown in [Table 3].

Table 3. Convergence core competency and team creativity technical statistics $(\mathrm{N}=104)$

\begin{tabular}{|c|c|c|c|c|}
\hline \multicolumn{2}{|c|}{ classification of questions } & M & SD \\
\hline $\begin{array}{c}\text { convergence core } \\
\text { competency }\end{array}$ & $\begin{array}{c}\text { Convergence } \\
\text { recognition capability }\end{array}$ & creative thinking & 3.34 & .915 \\
\cline { 3 - 5 } & critical thinking & 3.29 & .977 \\
\hline
\end{tabular}




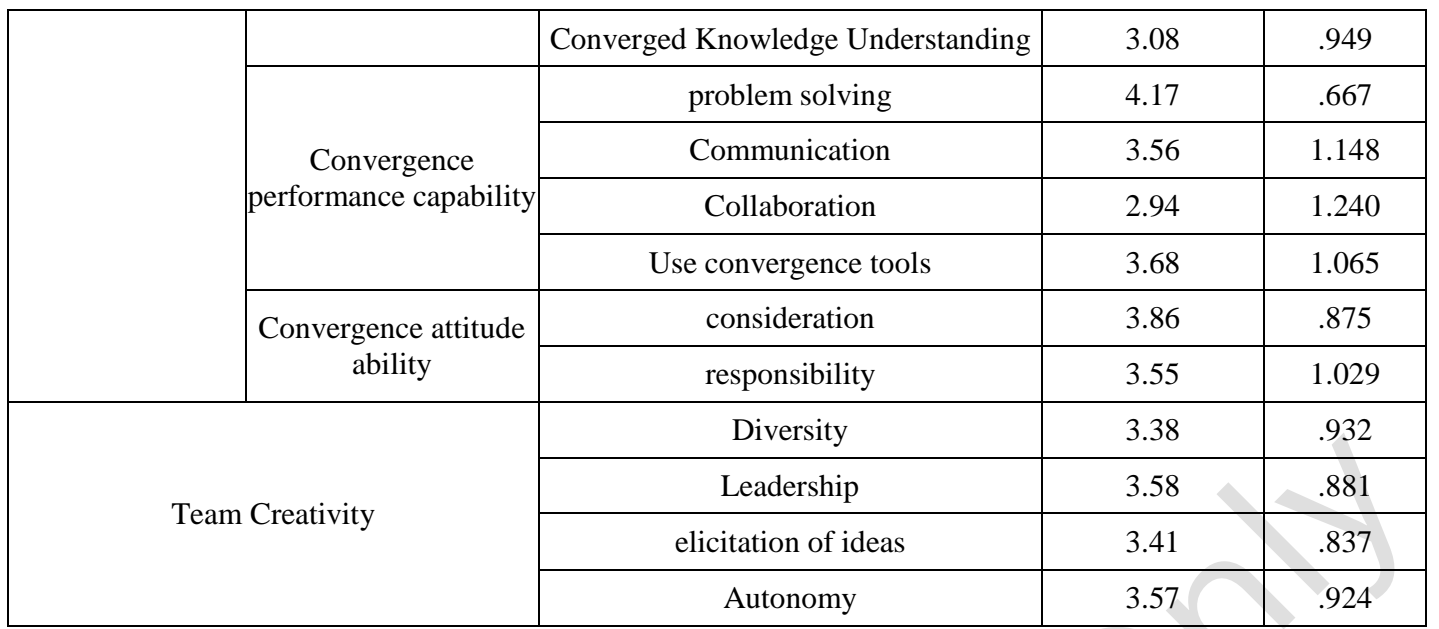

Among the convergence core competency of industrial workers, $\mathrm{M}(\mathrm{SD})$ of "creative thinking," a sub-factor of convergence cognitive ability, was 3.34(.915), M(SD) of " problem solving," a sub-factor of convergence performance, 4.17(.667), and M(SD), a sub-component of convergence core competency, were 3.86.875). Among them, "problem solving" was the highest. The level of team creativity was also the highest at 3.58 (.881) for 'leadership' and the lowest at 3.41 (.837) for 'elicitation of ideas'.

Pearson correlation analysis was performed to analyze the relationship between convergence core competency and team creativity. As a result of the correlation analysis, the convergence core competency and team creativity of the industry workers showed a significant correlation. The results are shown in [Table 4].

Table 4. Correlation analysis between convergence core competency and team creativity $(\mathrm{N}=104)$

\begin{tabular}{|c|c|c|c|c|c|c|c|c|c|c|c|c|c|}
\hline & $\left|\begin{array}{c}\text { Creativ } \\
\mathrm{e} \\
\text { thinkin } \\
\mathrm{g}\end{array}\right|$ & $\mid \begin{array}{c}\text { Critica } \\
1 \\
\text { thinkin } \\
\mathrm{g}\end{array}$ & $\begin{array}{c}\text { Converged } \\
\text { Knowledge } \\
\text { Understandi } \\
\text { ng }\end{array}$ & $\left|\begin{array}{c}\text { Proble } \\
\mathrm{m} \\
\text { solving }\end{array}\right|$ & $\begin{array}{c}\text { Communicati } \\
\text { on }\end{array}$ & $\mid \begin{array}{c}\text { Collaborati } \\
\text { on }\end{array}$ & $\begin{array}{c}\text { Use } \\
\text { convergen } \\
\text { ce tools }\end{array}$ & $\begin{array}{c}\text { Considerati } \\
\text { on }\end{array}$ & $\begin{array}{c}\text { Responsibili } \\
\text { ty }\end{array}$ & $\begin{array}{c}\text { Elicitati } \\
\text { on of } \\
\text { ideas }\end{array}$ & $\begin{array}{c}\text { Diversit } \\
\mathrm{y}\end{array}$ & $\begin{array}{l}\text { Leadersh } \\
\text { ip }\end{array}$ & $\begin{array}{c}\text { Autono } \\
\text { my }\end{array}$ \\
\hline $\begin{array}{l}\text { Creative } \\
\text { thinking }\end{array}$ & 1 & & & & & & & & & & & & \\
\hline $\begin{array}{c}\text { Critical } \\
\text { thinking }\end{array}$ & $.512 * *$ & 1 & & & & & & & & & & & \\
\hline Converged $\sim$ & $.351^{* * *}$. & $.413 * *$ & 1 & & & & & & & & & & \\
\hline $\begin{array}{c}\text { Problem } \\
\text { solving }\end{array}$ & $.369 * *$. & $.465 * *$ & $.447 * *$ & 1 & & & & & & & & & \\
\hline \begin{tabular}{|c|} 
Communicati \\
on
\end{tabular} & $.349^{* * *}$. & $.367 * *$ & $.395^{* *}$ & $.569 * *$ & 1 & & & & & & & & \\
\hline Collaboration & .146 . & $.340^{* * *}$ & $.450^{* *}$ & $.378 * *$ & $.549^{* * *}$ & 1 & & & & & & & \\
\hline $\begin{array}{c}\text { Use } \\
\text { convergence } \\
\text { tools }\end{array}$ & $.358 * *$. & $.293 * *$ & $.665 * *$ & $.370 * *$ & $.323^{* * *}$ & $.393 * *$ & 1 & & & & & & \\
\hline Consideration & \begin{tabular}{|l|}
.123 \\
\end{tabular} & $.203 *$ & $.319 * *$ & $.226 *$ & $.412 * *$ & $.633^{* * *}$ & $.232 *$ & 1 & & & & & \\
\hline \begin{tabular}{|c|} 
Responsibilit \\
$\mathrm{y}$ \\
\end{tabular} & $.376^{* * *}$. & $.362 * *$ & $.347^{* *}$ & $.388^{* *}$ & $.393^{* * *}$ & $.524 * *$ & $.361^{* *}$ & $.566 * *$ & 1 & & & & \\
\hline $\begin{array}{c}\text { Elicitation of } \\
\text { ideas }\end{array}$ & $.468 * *$. & $.265 * *$ & .190 & $.260 * *$ & $.293 * *$ & $.308^{* *}$ & $.261 * *$ & $.343 * *$ & $.450^{* * *}$ & 1 & & & \\
\hline Diversity & $.235^{*}$ & .175 & .165 & .068 & -.033 & .053 & .122 & .100 & .118 & $.456^{* *}$ & 1 & & \\
\hline Leadership & $.310 * *$ & .063 & .162 & .177 & .166 & $.210^{*}$ & $.206 *$ & .157 & .152 & $.609 * *$ & $.370 * *$ & 1 & \\
\hline Autonomy & .316** & \begin{tabular}{|l|l|}
$.218^{*}$ \\
\end{tabular} & $.237^{*}$ & .146 & $.291^{* *}$ & .166 & $.254 * *$ & .145 & .150 & $.515^{* *}$ & $.411 * *$ & $.609 * *$ & 1 \\
\hline
\end{tabular}

The correlation between convergence core competency and team creativity resulted in significant correlation between all the variables $(\mathrm{p}<.001)$, all of the lower factors of 
convergence core competency, showed static correlation with team creativity. Also, the highest static correlations was shown to creative thinking and elicitation of ideas $(r=.468$, $\mathrm{p}<.001$ ), and these results can be predicted to be the ability to think creatively, the convergence core competency that represents the highest correlation with team creativity.

\subsection{Hypothesis 2 - The convergence core competency of industry workers will affect team creativity}

A simple regression analysis was conducted to analyze the impact of convergence core competency of industry workers on team creativity. The analysis results are shown in [Table $5]$.

Table 5. Regression analysis of convergence core competency on team creativity $(\mathrm{N}=104)$

\begin{tabular}{|c|c|c|c|c|c|c|c|c|}
\hline \multirow{2}{*}{\multicolumn{2}{|c|}{ Independent variable }} & \multirow{2}{*}{$\begin{array}{c}\text { Dependent } \\
\text { variable }\end{array}$} & \multicolumn{2}{|c|}{$\begin{array}{l}\text { Unstandardized } \\
\text { regression coefficients }\end{array}$} & \multirow{2}{*}{$\begin{array}{c}\begin{array}{c}\text { Standardized } \\
\text { regression } \\
\text { coefficients }\end{array} \\
\text { B }\end{array}$} & \multirow{2}{*}{$\mathrm{T}$} & \multirow{2}{*}{$\begin{array}{l}\mathrm{R} 2 \\
(\delta \mathrm{r} 2)\end{array}$} & \multirow{2}{*}{$\mathrm{F}$} \\
\hline & & & B & Standard & & & & \\
\hline \multirow{2}{*}{1} & (constant) & \multirow{2}{*}{$\begin{array}{l}\text { Team } \\
\text { creativity }\end{array}$} & 2.612 & .194 & & $13.440 * * *$ & \multirow{2}{*}{$\begin{array}{l}.174 \\
(.166)\end{array}$} & \multirow{2}{*}{$21.518 * * *$} \\
\hline & $\begin{array}{l}\text { Creative } \\
\text { thinking }\end{array}$ & & .255 & .055 & & $4.639 * * *$ & & \\
\hline \multirow{3}{*}{2} & (constant) & \multirow{3}{*}{$\begin{array}{c}\text { Team } \\
\text { creativity }\end{array}$} & 2.202 & .277 & & $7.940 * * *$ & \multirow{3}{*}{$\begin{array}{l}.207 \\
(.191)\end{array}$} & \multirow{3}{*}{$13.183 * * *$} \\
\hline & $\begin{array}{l}\text { Creative } \\
\text { thinking }\end{array}$ & & .242 & .055 & .395 & $4.423 * * *$ & & \\
\hline & Consideration & & .119 & .058 & .182 & $2.044 *$ & & \\
\hline
\end{tabular}

The validation of Model 1 analyzed that the creative thinking set as a control variable was statistically significant $(\mathrm{F}=.174, \mathrm{p}<.001)$. The modified $\mathrm{R}^{2}=.166$, the independent variable, Creative Thinking, was analyzed to describe team creativity by $16.6 \%$. In addition, creative thinking has a statistically significant positive effect on team creativity $(\beta=.417, \mathrm{p}<.001)$.

The verification results of Model 2 showed an increase of $2.5 \%\left(\Delta \mathrm{R}^{2}=.025\right)$ to the revised $\mathrm{R}^{2}=.191$, and an increase in creative thinking $(\beta=.395, \mathrm{p}<.001)$ and caring $(\beta=.182, \mathrm{p}<.001)$ among the subcomponents of converged core capabilities and. It was analyzed that 182 , $\mathrm{p}<.001)$, had a statistically significant positive effect on team creativity. The control variable, Creative Thinking, was shown to have a statistically significant effect on team creativity in Model 1, and also a statistically significant effect on Model 2. Also, when compared with the standardized beta value $(\beta)$, the effect on creativity of the team was higher in the order of creative thinking and consideration. Beta means that team creativity changes in the same direction and size when the convergence core competency of creative thinking and consideration increase. The regression formula derived from these results is as follows.

$$
\text { Team creativity }=2.202+.242 \text { (creative thinking) }+.119 \text { (consideration) }
$$

According to the derived regression formula, if creative thinking and consideration are zero, the average of team creativity is 2.202 , and if creative thinking increases by one point, 
the average of team creativity will increase by 0.242 points, and if caring increases by one point, the average of team creativity will increase by 1.119 points. However, the results of this study have limitations in generalizing the results, given that convergence core competency are only about 20 percent of team creativity.

\section{Conclusion and discussion}

\subsection{Conclusion}

This study addresses the sustainability of society as a whole by promoting the team creativity of industrial workers. In particular, it can be used as a basic model to drive the sustainability of the social economy as an empirical study confirming the impact of convergence core capabilities on team creativity in the era of the Fourth Industrial Revolution. In addition, depending on the occupational groups of the industry workers studied in this study, the core competencies required for them may vary. Nevertheless, this study is meaningful as an empirical study to present the model of convergence core capacity as a common requirement among industrial workers.

In conclusion, we analyzed the effect of industrial worker's core competence on team creativity output based on a review of several previously published studies. Creative thinking and the consideration of core competence of team members were found to influence team creativity. Kwon et al. (2018) conducted a survey of senior managers of Korean shipyards with an emphasis on communication competence based on the consideration of the characteristics of team members for organizational management and success [14]. Like Leonardo da Vinci, the time has come for a genius to do everything. In order to live in an era where experts from various fields work together to accomplish one big task, it is important to recognize that team creativity is more important for individual college students than individual creativity. Thus, it is necessary to emphasize creativity at the team and group level. This necessity for education should be extended to society as a whole.

\subsection{Discussion}

Facing of an era when the Fourth Industrial Revolution is becoming a reality and interest in future education methods to prepare for it are increasing around the world, traditional instructor-style teaching methods have limitations in promoting learners' continued team creativity. Therefore, many educators have recognized that there is a limit to fostering talented people who can demonstrate team creativity through existing education methods, and there is a growing awareness that new educational attempts and applications are urgently needed [15]. In particular, Root-Bernstein, an art historian, developed a variety of methods for observing, shaping, abstraction, pattern recognition, pattern formation, analogy, body thinking, empathy, dimensional thinking, and modeling; in total 13. Ideas were proposed [16]. As a result of this change, research on teaching methods that can induce creative ideas for students has been initiated in Korea, instead of teaching one-sided content. The design of various group activities such as discussion methods and cooperative learning that involves listen to the opinions of other people has been undertaken, with the aim of demonstrating team creativity by internalizing the consideration of all members in the team.

In addition, entrepreneurship education is offered as a core educational method to cultivate the ability to develop innovative technologies based on creative thinking and to cultivate talented individuals with continuous adaptability as team members [17]. If general education is based on learning, then entrepreneurship education is empirical learning based on the idea 
of an individual or a team. In other words, entrepreneurship education places a greater emphasis on vision and creativity. This approach may help students to develop strategies to run themselves, as well as developing entrepreneurship and creativity among the whole team.

Project learning is a form of learning in which learners explore and collaboratively solve issues by solving complex, unstructured, and realistic problems. Team project-based learning is used in many college classes because its educational effectiveness is acknowledged in terms of utilizing and creating knowledge through tasks based on real-world context. In particular, creative knowledge through collaboration with team members enables learners to learn and perform at a higher level [18]. As such, universities, which are institutions in charge of future education that at the same time foster high-quality manpower for future society, should strive to continuously promote team creativity through various educational methods.

Many researches have expressed great interest in creativity in various aspects of companies and schools. However, the subject is mostly focused on the individual dimension. The results of this study suggest the necessity of research on team creativity in addition to the general interest in teams. In order to effectively manage a team project type education in a higher education context, it is necessary to support the program that can improve the teaching proficiency of the instructor. Also, educational content centered on the convergence ability that can actually enhance team creativity in the classroom is required. Finally, further research on the methodology should be actively carried out in the future.

Despite the theoretical and empirical significance of this study, this study also had some limitations. First, in selecting samples, it is difficult to list industry workers in various fields. A large number of samples can be obtained by selecting a single large company in the course of the study. However, this could not be obtained in the present study because the review sampled people working for various industries. Therefore, further studies will need to be conducted on workers in more diverse industries and organizations. Second, this study investigates what factors among the core competencies of industrial workers affect team creativity, and neglecteds the fact that the types and characteristics of teams can act as interference factors. Therefore, further research should be done on the general characteristics of the types and characteristics of the team, not individual workers.

\section{References}

[1] J. H. Sim, Y. R. Lee, and H. K. Kim, "Understanding STEM, STEAM education, and addressing the issues facing STEAM in the Korean context." Journal of the Korean Association for Research in Science Education, vol.35, no.4, pp.709-723, (2013) DOI: 10.14697/jkase.2015.35.4.0709

[2] KIRD. "Study of establishment of convergence concept and convergence core competence, Technical Report-2015," Chungju: Korea Institute of Human Resources Development in Science and Technology, (2015)

[3] KCTPA, "Korea Convergence Technology Promotion Agency, Test of Aligned Convergence Capabilities of Enterprises and Organizations," Retrieved 15, December, http://www.ct.or.kr/alignedconvergence/ self_as sessment.jsp, (2017)

[4] M. H. Lee, "Prerequisite for success of technology commercialization", Digital Times, http://m.dt.co.kr /contents.html?article_no=2014062502012251796002, (2014)

[5] WEF, "The future of jobs: employment, skills and workforce strategies for the forth industry revolution", Colony/Geneva: World Economic Forum, Jourary, (2016)

[6] A. C. Kay and C. Z. Koval, "A gender bias in the attribution of creativity: Archival and experimental evidence for the perceived association between masculinity and creative thinking," Psychological Science, vol.26, no.11, pp.1751-1761, (2015) 
[7] Rahimi F., Møller C., and Hvam L. "Business Process Management and IT Management: The Missing Integration,” International Journal of Information Management, vol.36, no.1, pp.142-154, (2016)

[8] Wheelen T. L., Hunger J. D., Hoffman A. N., and Bamford C. E, "Strategic management and business policy," NJ, Prentice Hall, (2017)

[9] Nienaber A. M. I., V. Holtorf J. Leker and G. Schewe, "A climate of psychological safety enhances the success of front end teams," International Journal of Innovation Management, vol.19, no.2, pp.1-34, (2015)

[10] Korea Employers Federation, "Capacity-based employment interview technique and evaluation SKILL UP," Seoul: Korea Employers Federation, (2012)

[11] C. S. Burke, K. C. Stagl, E. Salas, L. Pierce, and D. Kendall, "Understanding team adaptation: a conceptual analysis and model," Journal of Applied Psychology, vol.91, no.6, pp.1189, (2006)

[12] K. M. Park, "Development of Key Competency Factors for Measuring Study Outcomes in Science, Technology, Engineering, Arts, Mathematics (STEAM),” Korean technology education association, vol.14, no.2, pp.234-257, (2014)

[13] J. I. Choi and H. S. Kim, "A study of the taking curvilinear approach between ethical leadership and innovative performance: Focused on the moderating effect of team duration," Korean academy of organization and management, vol.39, no.4, pp.55-88, (2015)

[14] A. M. Kwon, H. Park, H. Hahn, I. Y. Lee, and T. H. Kwon, "Motivators of MBWA and communicational factors behind them: a case study on a korean shipyard,” J. Open Innov. Technol. Mark. Complex. vol.4, no.3, pp.29, (2018) DOI: 10.3390/joitmc4030029

[15] Korea Education and Research Information Service, "A study on the effectiveness of SW education school in 2015 (Research Report RR 2015-6)," Daegu Metropolitan City: Korea Education and Research Information Service, (2015)

[16] Jeon M. K., "Suggestion of composition of art and idea tool based on artist's idea," M.S. thesis, Gyeongin National University of Education, (2018)

[17] Chung C. G., "Current status and tasks of university entrepreneurship education for young entrepreneurship activation," The HRD review, pp.40-59, (2013)

[18] Whang J. Y., "A study on the effects of team project-led entrepreneurship education on the university student's entrepreneurship and problem-solving ability," M.S. thesis, Dankook University, (2017)

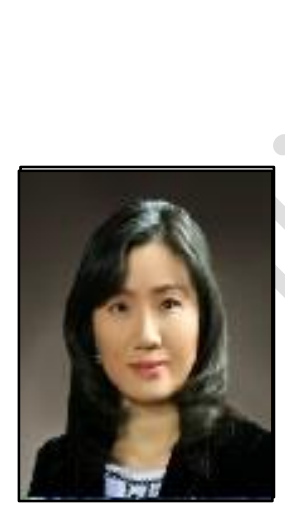

\section{Authors}

\section{Eun.Joo Kim}

EunJoo Kim, Ph.D. is a Professor of Liberal Art at Eulji University, Korea. She is a graduate of the Department of Education at Kookmin University in Korea, and the areas of research that are interested are managing the quality of education such as learners' learning experience, learning performance and education evaluation, creativity education. 
An Analysis of Convergence Core Competency Affecting Team Creativity of Industrial Workers

This page is empty by intention. 